\title{
BAHASA SUNDA DIALEK PANGANDARAN \\ DI KECAMATAN SIDAMULIH \\ (Kajian Fonologis)
}

\author{
Temmy Widyastuti \\ Departemen Pendidikan Bahasa Daerah FPBS UPI \\ Pos-el: temmy.widyastuti@upi.edu
}

\begin{abstract}
Abstrak
Penelitian ini dilatarbelakangi oleh perbedaan variasi bahasa masyarakat dalam satu wilayah bahasa yang bisa mengakibatkan perbedaan pemahaman. Seperti diungkapkan dalam geografi dialek bisa saja hal tersebut dilatarbelakangi oleh lapisan masyarakat berdasar usia, pekerjaan ataupun pendidikan. Metode yang digunakan adalah metode deskriptif, dengan observasi, wawancara, kuesioner dan analisis padan. Tujuan penelitian ini untuk memperoleh gambaran mengenai kondisi kebahasaan masyarakat Pangandaran Kecamatan Sidamulih khususnya dalam kajian fonologi. Hasil dari penelitian ini menjelaskan dialek masyarakat kecamatan Sidamulih Pangandaran yang berkaitan dengan fonologi, yaitu penambahan vokal ataupun konsonan dalam kata yang digunakan dan perbedaan semantis dari variasi bahasa yang digunakan.
\end{abstract}

Kata kunci: dialek, bahasa Sunda, Kecamatan Sidamulih Pangandaran

\section{PANGANDARAN SUNDANESE DIALECT IN SIDAMULIH (Phonological Study)}

\begin{abstract}
This research is motivated by language variation differences in one area of the language that can lead to differences in understanding. As expressed in the geography of the dialect, it can be caused by the differenciation of the society based on age, occupation or education. The method used is descriptive method, with observation, interview, questionnaire and comparative analysis. The purpose of this study is to obtain a description of the language condition of Pangandaran people in Sidamulih especially in the study of phonology. The results of this study explain the dialect Pangandaran people in Sidamulih that related with phonology. It reveals that there is the addition of vowel or consonant in the word used and the semantic difference of language variation used.
\end{abstract}

Keywords: Dialect, Sundanese Language, Sidamulih Pangandaran

\section{PENDAHULUAN}

Dialek sebagai variasi bahasa dapat dilihat dari beberapa pandangan para ahli seperi Ayatrohaedi (Wahya 2010:4) menjelaskan bahwa dialek adalah sebuah sistem bahasa yang digunakan oleh salah satu masyarakat, yang berbeda dengan masyarakat lainnya dalam rumpun yang sama dengan sistem yang berbeda. Menurut Richard (Wahya 2010:4) dialek yaitu satu variasi bahasa yang digunakan di sebagian negeri (dialek regional atau regiolek) atau masyarakat yang mempunyai kelas sosial (dialek sosial atau sosiolek). 
Pada perkembangannya, dialek sosial dalam kajian dialektologi mengacu pada dialek yang dituturkan oleh penutur daerah tertentu berdasarkan variabel sosial penuturya. Dialek ini dimungkinkan mengalami perbedaan antara penutur dan variabel sosial tertentu dengan variabel sosial yang lain meskipun mereka berada dan berasal di daerah yang sama. Perbedaan tersebut dapat terlihat dari beberapa kelompok yang terdiri dari usia, pekerjaan, jenis kelamin, pendidikan dan sebagainya (Zulaeha 2010:29).

Penelitian dialek yang dilaksanakan di Kabupaten Pangandaran dilatarbelakangi oleh kekhasan dialeknya. Kabupaten Pangandaran terdiri dari 10 Kecamatan, 92 Desa. Dari beberapa kecamatan, penelitian ini dilaksanakan di Kecamatan Sidamulih dengan sampel dari desa Kersaratu, Sidamulih dan Cikembulan dengan target informan dari usia 30-80 tahun yang sudah lama tinggal di desa tersebut. Adapun informan dilihat pula dari segi pekerjaan dan latar belakang pendidikan. Ketiga aspek informan tersebut menjadi acuan peneliti karena akan mempengaruhi pembendaharaan kata yang dikuasainya. Analisis kajian dalam penelitian ini terfokus pada sisi fonologi yaitu bunyi bahasa yang berfungsi dalam ujaran dan yang dapat membedakan makna itulah yang menjadi objek salah satu disiplin linguistik (Pateda, 2011).

Keanekaragaman bahasa, tentu tidak lepas dari beragamnya kosa kata. bahasa Sunda pada masing-masing daerah tentu memiliki kekhasan masing-masing (Mulatsih, 2016), namun meskipun samasama berada di wilayah Jawa Barat, dalam artian bahasa Sunda menjadi bahasa daerahnya, tetapi Kabupaten Pangandaran termasuk daerah yang mempunyai kekhasannya sendiri, terutama dalam pembentukan kata dan makna.

Bahasa Sunda adalah bahasa yang digunakan masyarakat Pangandaran dalam berkomunikasi sehari-hari. Namun seiring berkembangnya zaman dan semakin banyak wisata yang disuguhkan di Kabupaten Pangandaran ini menarik wisatawan domestik maupun luar negeri, yang datang dengan bahasa yang berbeda, dalam jangka panjang hal ini akan berdampak pula pada penggunaan bahasa di masyarakat setempat. Saat ini pada beberapa wilayah, masyarakat tutur di Kabupaten Pangandaran menggunakan bahasa Jawa dalam berkomunikasi seharihari karena Kabupaten Pangandaran ini berbatasan dengan Jawa Tengah khususnya daerah Cilacap. Sehingga di Kabupaten Pangandaran ini setidaknya ada tiga bahasa yang mendominasi percakapan masyarakatnya sehari-hari di antaranya, bahasa Sunda sebagai bahasa ibu, bahasa Indononesia, dan bahasa Jawa. Peneliti memilih kabupaten Pangandaran sebagai objek penelitian karena adanya persinggungan dari tiga bahasa tersebut, dengan kajian sosiodialektologi akan diketahui keberanekaragaman bahasa, dan faktor-faktor yang mempengaruhinya khususnya dari sisi fonologisnya.

\section{METODE PENELITIAN}

Metode yang digunakan dalam penelitian ini adalah metode deskriptif dengan teknis analisis padan yang berarti sama dengan perbandingan, artinya satu hal yang memiliki makna serta berhubungan. Oleh sebab itu padan dalam kontes ini diarikan sebagai hubunganbandingan (Mashun, 2005:117). tehnik ini digunakan untuk menganalisis adanya perbedaan unsur kebahsaan Bahasa Sunda dialék Pangandaran Kecamatan Sidamulih dan Bahasa standar atau bahasa Sunda lulugu, tehnik lainnya adalah kuesioner, wawancara, dan observasi.

\section{HASIL DAN PEMBAHASAN}

Masyarakat Kecamatan Sidamulih banyak yang menggunakan bahasa Sunda dalam kegiatan sehari-harinya walaupun kebanyakan masyarakat di kecamatan 
Sidamulih adalah pendatang dari luar Jawa Barat.

Penelitian ini dilaksanakan di tiga desa yang terdapat di kecamatan Sidamulih. Desa yang dijadikan objek penelitian adalah desa Cikembulan, desa Sidamulih, dan desa Kersaratu. Untuk mendapatkan data penelitian dari ketiga desa tersebut yaitu dengan membandingkan bahasa lulugu dengan bahasa yang biasa digunakan masyarakat Pangandaran dalam kehidupan sehariharinya, berdasarkan istilah-istilah dalam kehidupan sehari-hari seperti: istilah penyebutan keturunan (pancakaki), istilah kata ganti, istilah bagian-bagian rumah, istilah nama-nama peralatan rumah tangga, istilah makanan dan minuman, istilah penyakit, istilah pekerjaan, istilah tumbuhan dan hewan, istilah sifat-sifat manusia, istilah musim, kehidupan desa dan masyarakat (Zulaiha, 2010).
Dari 500 kata yang dibandingkan, ditemukan bermacam-macam istilah pemakaian bahasa Sunda di daerah tersebut. Sebagian ada yang serupa atau termasuk ke dalam bahasa lulugu, sebagian lagi ada yang memang hanya dipakai di daerah tersebut.

Pemakaian bahasa Sunda di kecamatan Sidamulih memang berbeda dengan bahasa Sunda baku. Dari kata yang dibandingkan tersebut, terdapat 237 variasi kata yang berbeda dengan bahasa Sunda baku. Banyak kata yang pemakaiannya berbeda di daerah tersebut. Hal tersebut dikarenakan banyak pendatang dari luar kabupaten Pangandaran, contohnya di desa Cikembulan banyak pendatang dari Jawa Tengah.

Beberapa bentuk kata yang dianggap berbeda atau bahasa dialek yang terdapat di kecamatan Sidamulih kabupaten Pangandaran bisa dilihat di tabel berikut.

Tabel 1

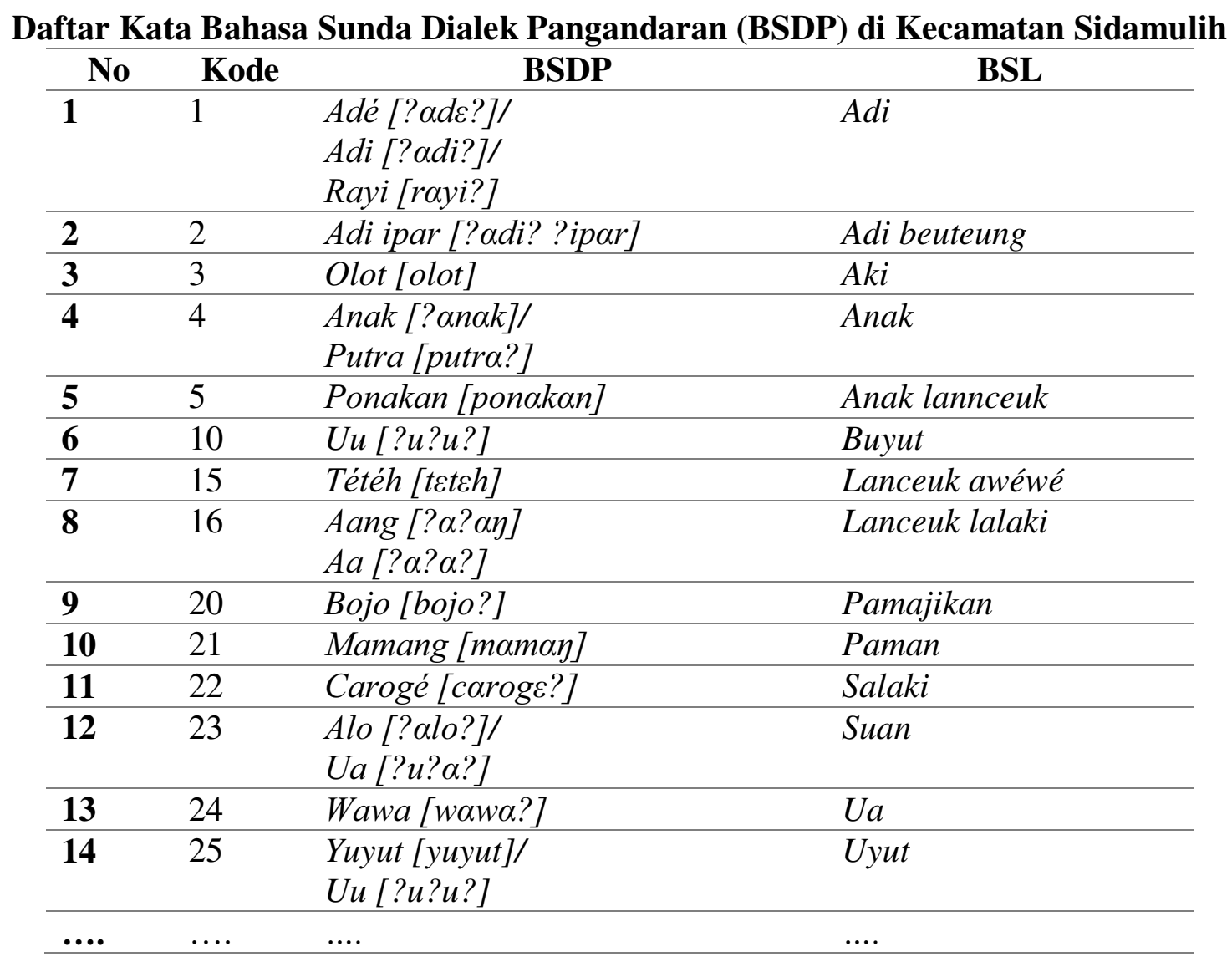


Makna Dasar Bahasa Sunda Dialek
Pangandaran di kecamatan Sidamulih

Dari hasil analisis data, makna dasar
Sidamulih berdasarkan 12 istilah kata, bisa dideskripsikan pada tabel di bawah ini.

dialek Pangandaran di kecamatan

Tabel 2

Daftar Makna Dasar Bahasa Sunda Dialek Pangandaran di Kacamatan Sidamulih

\begin{tabular}{clcc}
\hline No & \multicolumn{1}{c}{ Ma'na Dasar } & F & \% \\
\hline 1 & Istilah keturunan (pancakaki) & 14 & 5.91 \\
\hline 2 & Istilah kata ganti & 10 & 4.22 \\
\hline 3 & Istilah bagian-bagian rumah & 10 & 4.22 \\
\hline 4 & Istilah peralatan rumah tangga & 43 & 18.14 \\
\hline 5 & Istilah makanan \& minuman & 16 & 6.75 \\
\hline 6 & Istilah penyakit & 13 & 5.49 \\
\hline 7 & Istilah tumbuhan & 32 & 13.5 \\
\hline 8 & Istilah hewan & 36 & 15.19 \\
\hline 9 & Istilah sifat-sifat manusia & 32 & 13.5 \\
\hline 10 & Istilah pekerjaan & 8 & 3.38 \\
\hline 11 & Istilah musim dan keadaan alam & 12 & 5.1 \\
\hline 12 & Istilah kehidupan desa dan & 11 & 4.6 \\
& masyarakat & 237 & \\
\hline$\quad$ Jumlah & & \multirow{2}{*}{$\%$} \\
\hline
\end{tabular}

Dari tabel di atas bisa disimpulkan bahwa persentasi kosa kata bahasa Sunda dialek Pangandaran di kecamatan Sidamulih yang terdapat istilah keturunan (pancakaki) 5.91\%, istilah kata ganti $4.22 \%$, Istilah bagian-bagian rumah $4.22 \%$, Istilah peralatan $18.14 \%$, Istilah makanan dan minuman $6.75 \%$, Istilah penyakit $5.49 \%$, Istilah tumbuhan dan buah-buahan $13.5 \%$, Istilah hewan $15.19 \%$, Istilah sifatsifat manusia $13.5 \%$, Istilah pekerjaan $3.38 \%$, Istilah musim dan keadaan alam $5.1 \%$, Istilah kehidupan desa dan masyarakat $4.6 \%$.

\section{Istilah Keturunan (Pancakaki)}

Kosa kata yang terdapat istilah keturunannya, jika dipersentasikan mencapai $5.91 \%$, di antaranya yaitu kata adik: adé/adi/ rayi (adi), adi ipar (adi beuteung), kakek: olot (aki), anak/ putra (anak), Keponakan: ponakan (anak lanceuk),uyut: uu (buyut), kakak perempuan: tétéh (lanceuk awéwé), kakak laki-laki: aang/ aa (lanceuk lalaki), istri: bojo (pamajikan), paman: mamang (paman), suami: carogé (salaki), alo/ ua (suan), wawa (ua), yuyut/ uи (uyut).

\section{Istilah Kata Ganti}

Kosa kata yang terdapat istilah kata ganti orang mencapai $4,22 \%$, di antaranya yaitu kata pacar: kabogoh (beubeureuh), saya: urang/déwék/ abi (gaganti jalma ka i), kamu: sia/ manéh (gaganti jalma ka ii), manéh/ manéhna (gaganti jalma ka iii), nama panggilan: panggilan (nénéh), nama (ngaran), néng/ nyail ning/ ening (sesebutan keur awéwé budak), aceuk/ ceuceul emal nénél bibi (sesebutan keur awéwé kolot), dédél ujang/ nanang (sesebutan keur lalaki budak), ang/ aang/ mamang (sesebutan keur lalaki kolot). 


\section{Istilah Bagian Rumah}

Kosa kata yang terdapat pada istilah bagian rumah mencapai $4,22 \%$, di antaranya kecap buruan (bangbarung), para (galar), eurih (kandang embé), gedogan (kandang kuda), usuk/ kaso/ jukut (kaso-kaso), amparan (lampit), buruan/ karangan/ kebon (kaparangan), kamar/ kamar bobo (pangkéng), sawér (panyawéran), méhong (para seuneu).

\section{Istilah Peralatan}

Kosa kata yang terdapat pada istilah peralatan rumah tangga mencapai $18,14 \%$, di antaranya kata bubu/ susug/ sosog (badodon), buwu (bubu), céngék alit (caplak), jodang (gagang sirib), sampingan (gayoran), sisir (garu), siwur (gayung), jolang (gentong), tampir/ bilig (giribig), jala (heurap), jengkok (jojodog), dékol (kampak), kurung hayam/ carangka (karamba (hayam)), wadah/ géréngséng (karinjang), wajan (katél gedé), heurap/ jalal jarring (kecrik), kembung (kembu), lés kuda (kondali), parang (korang), keukeuh (kukuh), sédok/ caduk (lambit), talang (langko), gamparan (lilingga), katél (Géréngéng), balandongan (paratag), parukuyan (parupuyan), peso (paso), patok waos (patik), periuk (pendil), talenan/ carangka (Rajang), bedog (peso keur nyacag daging), rantang/ téngténgan/ blastrang (pontrang), pisin (posin), gorok (ragaji), pikulan (rancatan), keranjang/ salu (ranjang), pemuda (seuweu), jodang/ sirib alit (sirib), boboko (sumbul), bakiak/ paruntahan (tarumpah), gebog (tolombong), kobok/ kobokan (literan béas), panyimpenan sééng/leukeur (wadah sééng).

\section{Istilah Makanan dan Minuman}

Kosa kata yang terdapat pada istilah makanan dan minuman mencapai $6,75 \%$, di antaranya yaitu ranginang/ rangmang (ampyang), bubur sumsum (bubur lemu), gurih (gajih), jeroan jagong (janggél), bumbu uyah asem (kéré), leupeut/ buras (lontong), karédok (loték), opak sampeu (opak goréng), lalab asak (pecel), tumpi/ goréngan (rempéyék), kéjo/ nasi (sangu), nasi aking/ jarangking (sangu poé), sarundéng (serundéng), sémpoy/ tutuakan (tuak), bolokotok/ lodéh garing/ berkat campur (tumis sésa), ketan (ulén).

\section{Istilah Penyakit}

Kosa kata yang terdapat pada istilah penyakit mencapai $5,49 \%$, di antaranya yaitu kata gohgoy (batuk), bau baham (bau sungut), konéng/rodék (borok), rodék/ borok (borok nu nepi ka molongo), sésékéleun/ keram (Cécéngkéleun), kamisesegeun (eueuriheun), géndongeun (gondongeun), éncok (incok), pohoan (limpeuran), mengok (mengi), udur (muriang), kilat (salésér), budeg (torék).

\section{Istilah Pekerjaan}

Kosa kata yang terdapat pada istilah pekerjaan mencapai $3,38 \%$, di antaranya yaitu kata paraji/paraji sepit (béngkong), algojo/tukang gelut (logojo), panayangan/panjak (nayaga), buran (pamatang), empu (panday), guguni (paraji), garong (rampog), sumpit/ paninggaran (tukang sumpit).

\section{Istilah Tumbuhan dan Buah-buahan}

Kosa kata yang terdapat pada istilah tumbuhan dan buah-buahan mencapai $13,5 \%$, di antaranya yaitu calingcing (balingbing), barundas (baluntas), lobak/timun/mantang (boléd), pisang/paséh/manggala (cau kulutuk), Lombok (céngék), rombéh/kembang honjé/kocombrang (comrang), pisitan (dukuh), oyong/mémés (émés), nanas/danas (ganas), ganyong (ganyol), gandul (gedang), géndot (génjér), sukun (karikukun), gudé (hiris), jambu monyét (jambu médé), kacang gendul (kacang gondola/gondola), kacang ijo (kacang héjo), durén (kadu), nangka walanda (mandalika), kupa (ménténg), émés (oyong), paparé (paria), peuteuy (peundeuy), peté (peuteuy), peté sélong 
(peuteuy sélong), acéh/tundun (rambutan), kacang kurupuk/cicipir (roay), cabé/Lombok (sabrang), salédri (saladah), nyaliara (saliara), éso (tangkil), tebu (tiwu).

\section{Istilah Hewan}

Kosa kata yang terdapat pada istilah hewan mencapai $15.19 \%$, di antaranya yaitu kata Kikirik (Anak anjing), Itik (Anak éntog),Pitik (Anak hayam), Peuyik (Anak japati), Itik (Anak meri), Gudel (Anak munding), Pedét (Anak sapi), Bilatung (Anak ucing), Babi hutan (Babi), Begu (Bagong), Lubang (Belut gedé), Bogo; Bayong; Boncél (Boncél), Buhayak (Buhaya), Lauk saribu; Berenyit (Burayak), Pedet; Pédét (Cangkurileung), Luwak (Careuh), Bikang (Danten), Gabus (Deleg), Careuh; Bajing (Ganggarangan), Udang (Hurang), Hayam; Janggar; Jajanggar (Jajangkar), Papatong (Jongjolong), Dara; Merpati (Japati), Keuyeup; Keuyeup ageung (Kapiting), Lélé; Bogo (Keting), Menjangan; Kujang (Kidang), Kukupu (Kuтupu), Lauk (Lauk cai), Kancra (Lauk emas), Orang utan; Gorilla (Raja monyét), Keuyeup; Lauk laut (Rajungan), Héwan (Sato),Careuh; Célémés (Sigung), Tai kotok (Tai hayam), Kucing (Ucing), Mencek (Uncal).

\section{Istilah Sifat-Sifat Manusia}

Kosa kata yang terdapat pada istilah sifat-sifat manusiamencapai13.5\%, di antaranya yaitu kata Teu seueur (Ancin), Buraong; Émosian (Barangasan), Séép; Habis (Beak), Amrin; Angkuh (Bedegong), Teu kaopan; Barbarian (Belikan), Sieun; Sieunan (Borangan), Pinter; Tangkasan (Calakan), Julid (Culika), Sumpangsimpang; Talangké (Élodan), Isinan (Éraan), Goréng adat (Goréng lampah), Boros (Hambur), Heuras (Jeger), Kebluk; Keleked (Kalékéd), Sieunan; Borangan (Kecing), Kebluk; Sebul; Sebut (Kedul), Serem; Haseum, Judes (Kucem), Dusun (Kuuleun), Lengkap; Kumplit (Lengkep),
Kabuhulan (Melag), Teu seukeut; Kodol (Mintul), Ogoan (Ogo), Pajeujeut (Pabeulit), Ragem; Sasarengan; Kompak (Rampak), Teu cééhan (Rayungan), Randu (Réncéd),Tataékan (Sésélékét), Rajin (Singer), Adigung (Sombong), Wantéran; Conggah (Sonagar), Pusing; Sesah (Susah), Giatan; Trangginas (Tangginas).

\section{Istilah Musim dan Keadaan Alam}

Kosa kata yang terdapat pada istilah musim dan keadaan alam mencapai5.1\%, di antaranya yaitu kata Tampian ; Bagian (Bagbagan). Bobol (Balong bedah ku caah) ,Kota (Dayeuh), Gélédég; Gugur (guludug), Léléran ; Solobékan alit (Kotakan leutik), Kedung; Walungan (Leuwi), Reuheuk (Mega), Sérang (Sawah), Saringéngé ;Panonpoé (Srangéngé), Solokan (Susukan), Bagbagan;Jamban (Tampian), Ngijih (Usum ngijih).

\section{Istilah Kehidupan Desa dan Masyarakat}

Kosa kata yang terdapat pada istilah kehidupan desa dan masyarakat mencapai3.38 \%, di antaranya yaitu Tos rumah tangga; Rumah tangga anyar (Imahimah), Pesuruh;Akil kadus (Kabayan), Kuwu (Kapala désa), Kapala dusun;Golongan (Kapala kampong), Tukang bata (Lio), Marbot (Merebot), Pesuruh désa (Nu nungguan bale désa), Patri (Palédang), Amil (Panghulu), Wandra (Pulisi désa), Sérang (Sawah/ tanah inventaris lurah).

\section{Perbedaan Basa Sunda Dialek Pangandaran di Kecamatan Sidamulih dengan Basa Sunda Lulugu Perbedaan Fonetik}

Perbedaan fonetik berdasarkan teori yang ada, mencakup pada perbedaan dari jihat vokal dan konsonan. Perbedaan dari jihat vokal terdapat 15 kata, sedangkan dari jihat konsonan terdapat 21 kata. Vokal

Dari jihat vokal terdapat 16 kata yang ditemukan dengan 15 pola. 
1) Pola /é/ $\rightarrow / \mathrm{i} /$

Bentuk kata:

- adé - adi

- éncok-incok

2) Pola /eu/ $\rightarrow / \mathrm{u} /$

- keukeuh-kukuh

3) Pola /é/ $\rightarrow$ /a/

- Péso-paso

4) Pola $/ \mathrm{i} / \rightarrow / \mathrm{o} /$

- Pisin-posin

5) Pola $/ \mathrm{a} / \rightarrow / \mathrm{u} /$

- sarundéng - surundéng

6) Pola /é/ $\rightarrow / \mathrm{o} /$

- géndongeun-gondongeun

7) Pola $/ \mathrm{o} / \rightarrow / \mathrm{i} /$

- mengok-mengi

8) Pola /i/ $\rightarrow$ /é/

- kacang ijo - kacang héjo

9) Pola /e/ $\rightarrow /$ i/

- $t e b u$ - tiwu

10) Pola /e/+/e/+/e/ $\rightarrow / a /+/ e ́ /+/ e ́ /$

Bentuk kata:

- keleked-kalékéd

11) Pola /a/ $\rightarrow / \mathrm{e} /$

Bentuk kata:

- lengkap - lengkep

12) Pola /é/ $\rightarrow$ /u/

Bentuk kata:

- gélédég - guludug

13) Pola /e/ $\rightarrow / \mathrm{u} /$

Bentuk kata:

- sesah-susah

14) Pola /a/ + - $\rightarrow$ /e/

Bentuk kata:

- marbot-merebot

15) Pola /a/+ /i/ $\rightarrow-+/ a /$

Bentuk kata:

- saringéngé - srangéngé

Dari beberapa kata di atas, pola yang lebih sering muncul dari pada pola yang lain adalah pola vokal /é/ $\rightarrow /$ i/ dengan jumlah 2 kata.

Konsonan

Dari jihat konsonannya, kata yang ditemukan yaitu 21 kata dengan pola konsonannya yaitu 20 pola.
1) Pola $/ y / \rightarrow-$

- yuyut-uyut

2) Pola $/ \mathrm{w} / \rightarrow / \mathrm{b} /$

- $\quad b u w u-b u b u$

3) Pola - $\rightarrow / \mathrm{ng} /$

- kembung - kembu

4) Pola $/ \mathrm{k} / \rightarrow / \mathrm{p} /$

- parukuyan - parupuyan

5) Pola /s/ $\rightarrow / \mathrm{c} /+/ \mathrm{ng} /$

- sésékéleun-cécéngkéleun

6) Pola /k/

- mengok-mengi

7) Pola /c/ $\rightarrow / \mathrm{b} /$

- calingcing - balingbing

8) Pola /r/ $\rightarrow / \mathrm{l} /$

- barundas - baluntas

9) Pola $/ \mathrm{k} /+/ \mathrm{b} / \rightarrow$ -

- kocombrang - comrang

10) Pola $/ \mathrm{m} / \rightarrow$ -

- mémés - émés

11) Pola /n/ $\rightarrow$ /g/

- nanas - ganas

12) Pola /d/ $\rightarrow / g /$

- danas - ganas

13) Pola /ng/ $\rightarrow$ /l/

- ganyong - ganyol

14) Pola /ny/ $\rightarrow$ /s/

- nyaliara - saliara

15) Pola /b/ $\rightarrow / \mathrm{w} /$

- tebu-tiwu

16) Pola $/ \mathrm{k} / \rightarrow$ -

- buhayak - buhaya

- kucing - ucing

17) Pola - + /d/ $\rightarrow / \mathrm{h} /+/ \mathrm{r} /$

- udang - hurang

18) Pola $/ \mathrm{g} / \rightarrow / \mathrm{k} /$

- jajanggar-jajangkar

19) Pola $/ \mathrm{k} / \rightarrow / \mathrm{m} /$

- $\quad$ kukири-kитири

20) Pola /r/ $\rightarrow$ -

- trangginas - tangginas

Dari beberapa pola di atas, hampir semuanya hanya mempunyai satu kata saja, kecuali pola $/ \mathrm{k} / \rightarrow$ - yang mencakup dua kata, terlihat bunyi kluster dalam kata tranginas menandakan bahwa adanya variasi bunyi konsonan, terlihat pula dalam 
penelitian lain (Rahayu, Vol. 1. No 2) bahwa perpaduan konsonan banyak terjadi pula dalam dialek bahasa jawa.

\section{Perbedaan Semantis}

Berdasarkan teori, perbedaan semantik adalah terbentuknya kata-kata baru berdasarkan perubahan fonologis atau pergeseran bentuk dengan bentuk yang beda. Dari kejadian ini, biasanya terjadi juga pergeseran arti dari kata tersebut. pergeseran itu berkaitan dengan dua hal, yaitu sinonimi atau persamaan arti dalam kata yang berbeda atau homonimi yang sama kata tapi memiliki perbedaan arti.

\section{Sinonimi}

Sinonimi atau padanan kata atau persamaan arti merupakan penanda yang beda untuk menentukan satu objek yang sama di berbagai tempat. Adapun perbedaan yang ditemukan dari jihat sinonimi di antaranya ada dalam tabel di bawah.

Tabel 3

Sinonimi Antara BSDP dan BSL

\begin{tabular}{|c|c|c|c|}
\hline No & Kode & BSDP & BSL \\
\hline (1) & $(2)$ & (3) & (4) \\
\hline 1 & 1 & 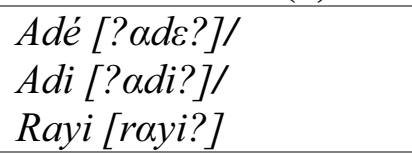 & Adi \\
\hline 2 & 2 & Adi ipar [? $\alpha$ di? ?ipar] & Adi beuteung \\
\hline 3 & 3 & Olot [olot] & $A k i$ \\
\hline 4 & 4 & $\begin{array}{l}\text { Anak [?anak]/ } \\
\text { Putra [putra?] }\end{array}$ & anak \\
\hline 5 & 5 & Ponakan [ponakan] & Anak lannceuk \\
\hline 6 & 10 & Uu [?u?u?] & Buyut \\
\hline 7 & 15 & Tétéh [tctch] & Lanceuk awéwé \\
\hline 8 & 16 & $\begin{array}{l}\text { Aang [?a? } \alpha \eta] \\
\text { Aa }[? \alpha ? \alpha ?]\end{array}$ & Lanceuk lalaki \\
\hline 9 & 20 & Bojo [bojo?] & Pamajikan \\
\hline 10 & 21 & Mamang [mamay] & Paman \\
\hline 11 & 22 & Carogé [caroge?] & Salaki \\
\hline 12 & 23 & 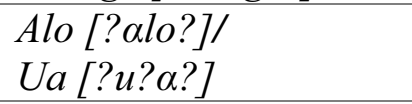 & Suan \\
\hline 13 & 24 & Wawa [wawa?] & $U a$ \\
\hline 14 & 25 & $\begin{array}{l}\text { Yuyut [yuyut]/ } \\
\text { Uu [?u?u?] }\end{array}$ & Uyut \\
\hline 15 & 27 & Kabogoh [kabogoh] & Beubeureuh \\
\hline 16 & 28 & 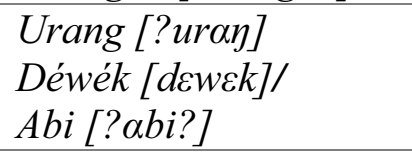 & Gaganti jalma ka 1 \\
\hline 17 & 29 & $\begin{array}{l}\text { Sia [si? a?]/ } \\
\text { Manéh [manch] }\end{array}$ & Gaganti jalma ka 2 \\
\hline$\ldots$ & & $\ldots$ & $\ldots$ \\
\hline
\end{tabular}




\section{Hominimi}

Sedangkan dari jihat homoniminya terdapat 9 kata yang dijabarkan dalam tabel di bawah:

\section{Homonimi antara BSDP dan BSL}

\begin{tabular}{|c|c|c|c|}
\hline No & Kode & BSDP & BSL \\
\hline 1 & 23 & $\begin{array}{l}\text { Ua } \\
\text { (sesebutan keur budak lanceuk) }\end{array}$ & $\begin{array}{l}\text { Ua } \\
\text { (sesebutan keur lanceuk indung } \\
\text { atawa bapa) }\end{array}$ \\
\hline 2 & 67 & $\begin{array}{l}\text { Bubu } \\
\text { (paragi ngala lubang tina awi } \\
\text { saleunjeur) }\end{array}$ & $\begin{array}{l}\text { Bubu } \\
\text { (paragi ngala lauk tina awi nu } \\
\text { dianyam) }\end{array}$ \\
\hline 3 & 231 & $\begin{array}{l}\text { Borok } \\
\text { (borok nu nepi ka molongo }\end{array}$ & $\begin{array}{l}\text { Borok } \\
\text { (kasakit nu nanahan) }\end{array}$ \\
\hline 4 & 369 & $\begin{array}{l}\text { Careuh } \\
\text { (sato nu kawas ucing, sok moro } \\
\text { hayam di sawah/leuweung ti } \\
\text { beurang) }\end{array}$ & $\begin{array}{l}\text { Careuh } \\
\text { (sato jiga ucing nu sok moro } \\
\text { hayam ti peuting) }\end{array}$ \\
\hline 5 & 254 & $\begin{array}{l}\text { Paraji } \\
\text { (nu sok nyepitan) }\end{array}$ & $\begin{array}{l}\text { Paraji } \\
\text { (nu sok ngabantuan nalika aya nu } \\
\text { ngalahirkeun) }\end{array}$ \\
\hline 6 & 293 & $\begin{array}{l}\text { Oyong } \\
\text { (sabangsaning sayuran nu sok } \\
\text { dihérang) }\end{array}$ & $\begin{array}{l}\text { Oyong } \\
\text { (sabangsaning sayuran nu kulitna } \\
\text { cucukan tur sok digaringkeun } \\
\text { dipaké ngaruru) }\end{array}$ \\
\hline 7 & 318 & $\begin{array}{l}\text { Émés } \\
\text { (sabangsaning sayuran nu } \\
\text { kulitna cucukan tur sok } \\
\text { digaringkeun dipaké ngaruru) }\end{array}$ & $\begin{array}{l}\text { Émés } \\
\text { (sabangsaning sayuran nu sok } \\
\text { dihérang) }\end{array}$ \\
\hline 8 & 431 & $\begin{array}{l}\text { Borangan } \\
\text { (jelema nu sieunan) }\end{array}$ & $\begin{array}{l}\text { Borangan } \\
\text { (sipat jelema nu borangan) }\end{array}$ \\
\hline
\end{tabular}

\section{Perbedaan Onomasiologis}

Kata-kata yang termasuk dalam kategori onomasiologis ada 14 kata, yaitu:

1) Kata olot. Kata ini mempunyai konsep yang hampir sama dengan kata aki, yaitu sebutan untuk seseorang yang dituakan. Kata ini berasal dari kata kolot atau tua, yang kemudian diterapkan untuk penyebutan kepada kakek.

2) Kata buruan. Kata ini mempunyai konsep yang hampir sama dengan kata bangbarung yang artinya ambang pintu. Kata buruan mempunya arti bahwa dari sana kita bisa mengawasi atau melihat keadaan di sekitar.

3) Kata sawér. Kata ini mempunyai konsep yang sama dengan kata panyawéran. Kata sawér di sini mempunyai arti air yang menetes dari genting yang mengenai bagian rumah. Tidak jauh beda dengan kata panyawéran dalam bahasa lulugu yang berarti bagian rumah yang terkena air dari genting ketika musim hujan.

4) Kata carangka. Kata ini mempunyai arti tempat ayam yang tebuat dari anyaman bambu yang carang. Tidak beda jauh dengan kata karamba hayam 
dalam bahasa lulugu yang berate anyaman dari bamboo.

5) Kata gorok. Kata ini mempunyai konsep yang hamper sama dengan kata ragaji dalam bahasa lulugu. Kata gorok berarti menggesekan alat pada kayu sampai kayu itu putus atau patah.

6) Kata pikulan. Kata ini mempunyai arti dan konsep yang hamper sama dengan kata rancatan dalam bahasa lulugu. Kata pikulan disini mempunyai konsep alat untuk memikul (serapan dari bahasa Indonesia).

7) Kata kobok/ kobokan. Kata ini mempunyai konsep bahwa untuk mengambil beras tinggal dikobok dengan kobokan.

8) Kata opak sampeu. Kata ini mempunyai konsep bahwa opak yang memasaknya dengan cara di goreng adalah opak sampeu. Karena di orang Sunda ada bergabai macam opak dan opak yang memasaknya digoreng adalah opak sampeu.

9) Kata bilatung. Kata ini mempunyai arti yang hampir sama dengan kata anak ucing. Kata bilatung ini memcerminkan banyaknya anak kucing dalam sekali melahirkan sehingga ketika dilihat utek-utekan seperti bilatung.

10) Kata lubang. Kata ini mempunyai konsep yang sama dengan kata belut gedé dalam bahasa lulugu. Kata lubang mempunyai konsep jenis ikan tawar yang hidup dalam lubang.

11) Kata lauk saribu. Mempunyai konsep karena banyaknya ikan yang bergerombol.

12) Kata dusun. Kata ini mempunyai konsep yang hampir sama dengan kata kuuleun. Kata dusun disini mempunyai arti yang sama dengan kampung. Jadi, kata dusun yang digunakan oleh masyarakat Pangandaran artinya seseorang yang kurang bergaulan.

13) Kata bobol. Kata ini mempunyai konsep untuk menunjukan sebuah kolam yang caah, sehingga ikanikannya terbawa arus.

14) Kata (489) kapala dusun/ golongan. Kata ini mempunyai konsep yang hampir sama dengan kata kepala kampung, yaitu seseorang yang menjadi pemimpin sebuah kampung.

\section{Perbedaan Semasiologis}

Kebalikan dari onomasiologis, perbedaan semasiologis adalah adanya kata yang mempunyai bergagai jenis konsep dalam pemakaian bahasanya. Adapun kata yang mempunyai perbedaan semasiologis yang terdapat dalam BSDP di kecamatan Sidamulih di antaranya adalah, kata $u u /$ yuyut dalam BSDP artinya (1) buyut, (2) uyut. Kata aal aang dalam BSDP artinya (1) lanceuk lalaki, (2) sesebutan keur lalaki kolot. Kata jodang/ sirib alit dalam BSDP arrtinya (1) gagang sirib, (2) sirib. Kata jala/ heurap/ jarring dalam BSDP artinya (1) heurap, (2) kecrik. Kata carangka dalam BSDP artinya (1) karamba (hayam), (2) Rajang. Kata pédét dalam BSDP artinya (1) anak sapi, (2) cangkurileung. Kata careuh dalam BSDP artinya (1) ganggarangan, (2) sigung. Kata sieunan dalam BSDP artinya (1) borangan, (2) kecing.

\section{SIMPULAN}

Kekhasan bahasa Sunda di bidang fonologi dan leksisikal di Kabupaten Pangandaran memiliki kekhasan. Desa yang dijadikan objek penelitian adalah desa Cikembulan, desa Sidamulih, dan desa Kersaratu. Dari penelitian ini dapat disimpulkan bahwa masyarakat Kecamatan Sidamulih masih menggunakan bahasa Sunda walaupun banyak pendatang baru. Dari segi kosa kata bahasa Sunda di kecamatan Sidamulih Kabupaten Pangandaran bisa disimpulkan bahwa pemakaian bahasa Sunda di kecamatan Sidamulih memang berbeda dengan bahasa Sunda baku. Dari kata yang dibandingkan tersebut, terdapat 237 variasi kata yang 
berbeda dengan bahasa Sunda baku. Terlihat penambahan dan pengurangan dan penambahan fonem dari dua bahasa yang diteliti juga perbedaan makna semantis menjadikan bahasa Sunda di Kabupaten Pangandaran memiliki ciri khas tersendiri.

\section{DAFTAR RUJUKAN}

Mahsun, M.S. 2005. Metode Penelitian Bahasa: Tahapan, Strategi, Metode, dan Tehniknya. Bandung: PT Grapindo Persada.

Mulatsih, Dewi. 2016. Inovasi Bentuk dalam Bahasa Sunda di Kampung Puyuh Koneng, Desa Kencana Harapan, Kecamatan Lebakwangi, Kabupaten Serang, Provinsi Banten. Jurnal Logika vol XVII No 2, Agustus 2016.
Pateda, Mansur. 2011. Linguistik Sebuah Pengantar. Bandung: Angkasa.

Rahayu, Ika Mamik. Dialek Bahasa Jawa di Kabupaten Ngawi. Skriptorium Vol. 1 No 2. Dalam http://journal.unair.ac.id/download.fu llpapersskriptorium75d25668full.pdf diunduh 7/6, 2017.

Wahya. 2010. Mengenal Sekilas Dialektologi. Bandung: Universitas Padjajaran

Zulaeha, Ida. 2010. Dialektologi: Dialek Geografi dan Dialek Sosial. Graha Ilmu: Yogyakarta.

\section{UCAPAN TERIMA KASIH}

Terima kasih kepada penyunting Jurnal Lokabasa yang berkenan dengan sangat teliti untuk memuat dan melakukan proses penerbitan Jurnal ini. 